\title{
КАЛДАРИЈУМИ У СКЛОПУ РИМСКИХ КУПАТИЛА КРОЗ АНАЛИЗУ ПРИМЕРА НА ТЛУ ИСТОЧНЕ И ЈУЖНЕ СРБИЈЕ: ГРАДИТЕЉСКИ КОНЦЕПТ И ОПРЕМАЫЕ
}

\author{
Игор Бјелић \\ Археолошки институт, Београд \\ e-mail: igor_bjelic@yahoo.com $\mid$ Прегледни рад \\ Примљено: 8. 4. 2021. УДК: 904:[725.1:613.41-027.555"652” \\ Прихваћено: 9. 6. 2021. \\ (497.11)
}

\begin{abstract}
Апстракт: Код појаве и развоја античких купатила пажну истраживача и шире јавности обично привлаче просторије за топле купке. Међу њима би требало посебно издвојити просторије за купање у врућој води, које се широко усвојеном терминологијом дефинишу као калдаријуми. У раду су анализиране међусобне сличности појединих римских купатила са припадајућим калдаријумима, на тлу источне и јужне Србије према архитектонским карактеристикама, при чему се посебно издвајају њихове основе, положај у склопу основа купатила и конструктивне карактеристике. Анализа наведених особина ових просторија указује да се у појединим случајевима мора извриити корекиија функиије појединих просторија у односу на раније објављене планове одређених купатила. У склопу истраживања размотрено је и место калдаријума у купатилима на тлу источне и јужне Србије у односу на појаву и развој ових просторија у ширем окружену.
\end{abstract}

Кључне речи: калдаријум, римско купатило, касноантичка архитектура, источна и јужна Србија

Увод

Грађење објеката у време Римског царства неретко је подразумевало карактеристично обликовање основе у зависности од њихове функције, префињену декорацију (употребу мозаика, фресака, мермерне оплате), специфичне конструкције и инсталације. На нашем тлу је лако препознати присуство већине ових елемената у античким објектима, али је много сложенија прецизна идентификација функције објекта и припадајућих просторија. Њихово присуство може указати да истражени објекат представља римско купатило, али оно свакако не сме бити посматрано као априори фактор на основу којег се може донети закључак о функцији објекта.

Одређивање функција просторија код античких грађевина на нашем тлу један је од најзахтевнијих проблема због високог степена њиховог 


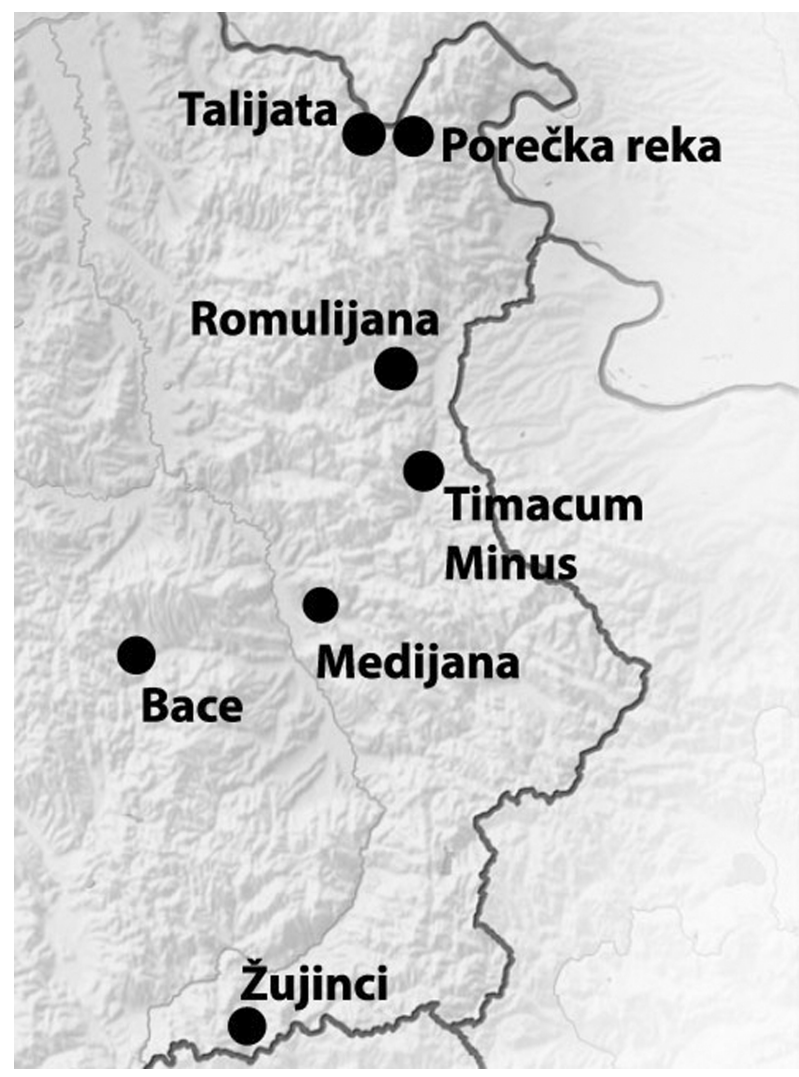

Сл. 1. Карта локалитета на којима се налазе римска купатила чији су калдаријуми предмет анализе (аутор, према сателитском снимку са сајта Google Earth)

Fig. 1. The map of sites where the Roman baths are located whose caldaria are the subject of the analysis (by the author, according to a satellite image from Google Earth)

оштећења, јер су неретко очуване у приземном нивоу или у нивоу темеља. Међу просторијама чије се постојање подразумева у склопу римских купатила свакако су фригидаријуми и тепидаријуми који су служили за купање у хладној, односно топлој води. У случају да су очувани на приземном нивоу или у нивоу темеља, одређене архитектонске карактеристике којима се одликују често се могу помешати са одликама просторија искључиво стамбеног карактера. Понекад је присуство инсталација као што су хипокауст, водовод или канализација узрок забуна у одређивању функције просторије или објекта, иако те структуре нису везане искључиво за термалне објекте. На пример, лако је на нивоу темеља помешати ауле, оекусе или триклинијуме као просторије стамбеног карактера са тепидаријумима купатила, јер обе врсте одаја подразумевају присуство наведених инсталација, а тепида- 
ријуми могу али не морају имати каде (на овај проблем претходно указују: Kuzmanović Novović et al. 2019, 31). Поред тога, разлике између појединих топлих просторија купатила (тепидаријума, лаконикума, судаторијума) на терену су често тешко препознатљиве. Слично, фригидаријуме је због присуства веће количине хидрауличног малтера и делимичне укопаности у односу на друге просторије купатила лако помешати са полуукопаним просторијама стамбеног карактера у којима је постојао проблем влаге, практично решаван применом поменутог малтера на подним и зидним површинама.

Материјалне могућности појединца или заједнице утицале су на величину купатила и степен његове опремљености, па је очекивано да су се мања купатила одликовала само најосновнијим садржајима, декорацијом и инсталацијама. У просторијама као што су аподитеријум или палестра, у мањим купатилима често нема ни потребе за специфичном декорацијом, као ни за специфичним инсталацијама. Штавише, у мањим купатилима се не морају наћи поједине од наведених просторија - најчешће недостају лаконикуми, судаторијуми, палестре. Међутим, независно од величине римског купатила и степена његове опремљености, тешко је замислити га без калдаријума - просторије чије се каде за вреле купке ослањају директно на конструкцију ложишта.

Сама појава и еволуција римских купатила била је условљена појавом калдаријума, о чему ће даље у тексту бити више речи. Излагање тела ваздуху засићеном паром и врелим купкама било је део римског луксуза, потребе, па и културе (Fagan 1999, 1; DeLaine 1988, 11; Yegül 1992, 30). Међутим, природне вреле купке у термалним изворима нису могле бити доступне свуда, тако да су се морале обезбедити на другачији начин - изградњом посебних просторија за ту сврху. Еволуција положаја ове просторије у склопу објекта, њене основе и опремања различитим врстама инсталација (водоводним, канализационим и хипокаустом), чини калдаријуме специфичном темом за проучавање. Усклађивање разнородних инсталација и конструкција са основом просторије и њеним положајем у склопу целине купатила сврстава калдаријуме међу специфична инжењерска достигнућа у архитектури античког света.

Присуство разнородних конструкција и инсталација у калдаријумима омогућава да се при археолошким истраживањима олакша њихово препознавање у односу на остале просторије купатила. Поред комплексног просторног односа специфичних конструкција и инсталација у њему, облик основе калдаријума и његов положај у односу на положај осталих просторија у склопу целине објекта подједнако су важни. Облик основе калдаријума 
се одликује специфичностима које намеће присуство када за врело купање и система за грејање и одржавање температуре.

На публикованим плановима римских купатила на тлу источне и јужне Србије, регистровани су случајеви када основа калдаријума није препозната. ${ }^{1}$ Недоумице око идентификације функције просторија у римским купатилима настају услед недостатка јасних критеријума у домаћој литератури (Kuzmanović Novović et al. 2019, 31). У овом раду покушаћемо да осветлимо карактеристике просторије калдаријума са више аспеката, како бисмо омогућили поузданије и лакше препознавање ових просторија у купатилима на наведеном тлу. Указаћемо на терминологију, појаву и развој специфичног плана и положај калдаријума у римској архитектури. Интерпретација остатака и коначна идентификација калдаријума у одређеним купатилима на тлу источне и јужне Србије посматрана је кроз неколико аспеката. То су анализе основа и положаја калдаријума у основи термалних објеката, анализе заступљених конструкција и инсталација, примењених материјала и унутрашње обраде. Анализама је обухваћено седам примера калдаријума појединих купатила на тлу источне и јужне Србије (сл. 1), односно купатила у Ромулијани, Талијати, Поречкој реци, Тимакум Минусу, Жујинцу, Бацу и Медијани, али ћемо указати и на њихове сличности са просторијама овог типа у окружењу. ${ }^{2}$

\section{Термин калдаријум}

За навођење термина калдаријум најбоље је ослонити се на познато Витрувијево дело (Vitruvius 1990, V, X) у коме он прави разлику између калдаријума, тепидаријума и лаконикума. То се види у наводима да вруће и топле просторије добијају светло са северозапада (ipsa autem caldaria tepidariaque lumen habeant ab occidente hiberno), да морају постојати три котла: један за врућу, други за топлу, и трећи за хладну воду (aenea supra hypocausim tria sunt componenda, unum caldarium, alterum tepidarium, tertium

\footnotetext{
${ }^{1}$ Идентификација калдаријума се као проблем појављује и код других купатила на територији Србије о чему је већ писано раније (за калдаријуме мањих купатила види: Јеремић, Гојгић, 2012: 22-27, за истраженост купатила на територији Србије види: Јеремић, Гојгић, 2012: табела 1; Janković 2012; Kuzmanović Novović et al. 2019.). Детаљније навођење и анализа сваког појединачних примера овде би одузело пуно простора, па их овом приликом нећемо детаљније разматрати.

${ }^{2}$ У нашим разматрањима римских купатила на тлу источне и јужне Србије изузета су купатила у Наисусу, Прокупљу, Тимакум Мајусу, Егети, која нису у потпуности истражена или нису објављени комплетни резултати њихових истраживања, а пре свега њихови планови. (За купатило у Тимакум Мајусу види: Петровић 1999: 56; Petrović, Filipović 2008; за Егету види: Petrović, Vasić 1996: 26).
} 
frigidarium) и да лаконикуме и судаторијуме треба спојити са топлим просторијама (laconicum sudationesque sunt coniungendae tepidario) (Vitruvius 1912, V, X, 114-115; Vitruvius 1990, V, X, 116-117). Према претходним наводима, калдаријум се у односу на остале просторије издваја као просторија намењена купању у врућој води.

Термин калдаријум до сада није регистрован на познатим римским натписима на тлу данашње Србије, као што није било ни других термина који би указивали на ове просторије. У недостатку другачијих термина, поверење по питању коришћења термина ипак бисмо указали раније наведеним познатим античким изворима. ${ }^{3}$ Исти однос према термину калдаријум широко је прихваћен у досадашњим истраживањима купатила на целој територији Римског царства (Krencker 1929; DeLaine 1988; Yegül 1992).

\section{Појава и развој калдаријума у римској архитектури}

Појава првих римских купатила, према Франческу ди Капуи, везана је за уверења присутна у народној медицини на централноиталском тлу, према којима се презнојавањем у загрејаној просторији побољшава циркулација људског организма и поспешује његово здравље (Yegül 1992, 50). ${ }^{4}$ Како се не би расипало гориво потребно за загревање просторија за презнојавање, оне су испрва биле придружене одаји за термичку обраду хране. Нешто касније је постало јасно да одаје намењене обради хране и одржавању личне хигијене не могу бити у истој просторији. Зато су ове активности раздвојене на две суседне просторије са заједничком пећи. Вода која се загревала у кухињи могла се спровести до суседног купатила.

Према истраживањима Фабрикотијеве, може се оквирно говорити о три фазе развоја калдаријума на централноиталском тлу (Yegül 1992, 50). Њена типолошка подела у развоју римских купатила изведена је према критеријуму међусобне близине купатила и кухиње и појави одређених инсталација. Према тој подели, постоје три типа, при чему код првог типа не постоји хипокауст, док се код преостала два он подразумева. Први и други тип

\footnotetext{
${ }^{3}$ Приписивање одређених термина просторијама римских купатила, као што је калдаријум, у последње три-четири деценије било је предмет извесних недоумица. Наиме, Ребуфат је приметио да се у документима на латинском језику ове просторије различито именују у појединим местима у Римском царству (Rebuffat 1991, 6-7). С. Марешал је управо из наведеног разлога указала да је за поједине просторије римских купатила тешко применити уједначену терминологију (Maréchal 2012, 146).

${ }^{4}$ Утицај стамбених објеката на централноиталском тлу на појаву и иницијални развој купатила у периоду сазревања римске цивилизације, у последње време доста су изучавали многи стручњаци који се баве римским купатилима (О значају тезе коју је поставио Ди Капуа види: Yegül 1992, 50; Fagan 1993, 29-72; Nielsen 1993, 1:20-2; Fagan 2001, 421-424; Maréchal 2012, 148).
} 

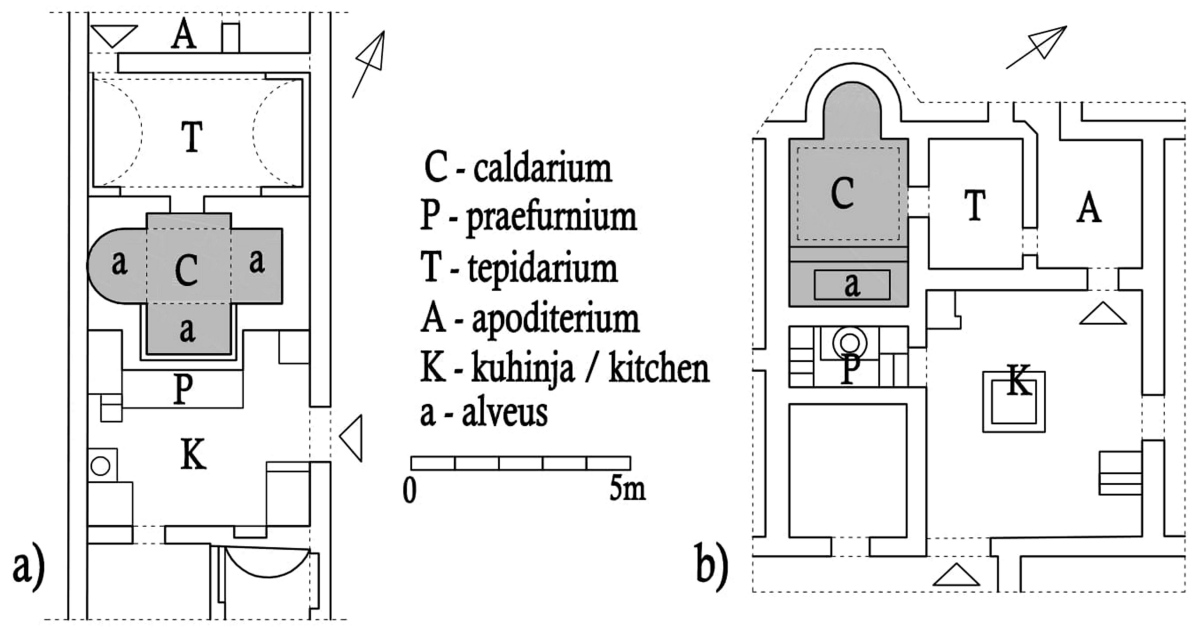

Сл. 2. Однос кухиње и купатила у римским кућама 1. века: a) Casa del Labirinto (цртеж аутора, према Overbeck 1884, fig. 175); б) Villa dela Pisanella, Боскореале (цртеж аутора, према Pasqui 1897, Tav. XIV)

Fig. 2. The relationship between the kitchen and the bath in Roman houses from the first century: a) Casa del Labirinto (drawing by the author, according to Overbeck 1884, fig. 175); б) Villa della Pisanella, Boscoreale (drawing by the author, according to Pasqui 1897, Tav. XIV)
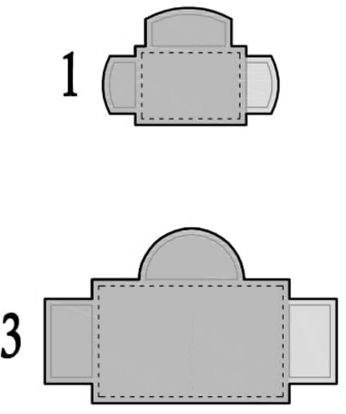
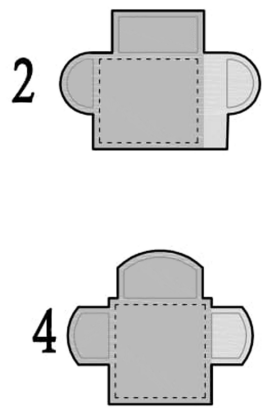
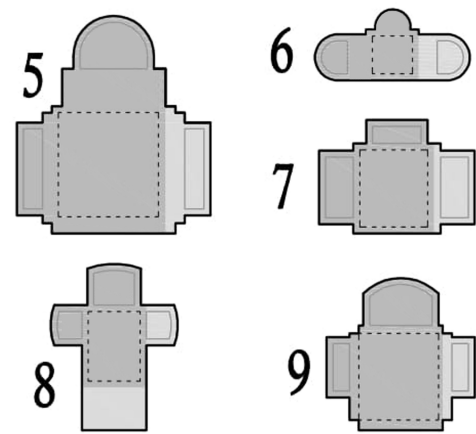

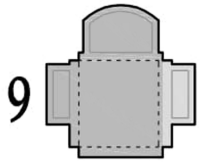

Сл. 3. Типови основа калдаријума код појединих купатила - модификован цртеж (према Krencker 1929, abb.241.a): тамносивим тоном означени су уобичајени садржаји, а светлосивим тоном опциони садржаји (аутор, према тумачењу Јегула, Yegül 1992, 50)

Fig. 3. Types of plans of caldaria in certain baths - modified drawing (according to Krencker 1929, abb.241.a): standard facilities are marked in dark gray, and optional facilities are marked in light gray (modified by the author, according to Yegül's interpretation, Yegül 1992, 50) 
купатила се одликују близином кухиње, пре свега међусобном близином кухиње и калдаријума. За разлику од прва два, трећи тип се одликује независним планирањем римског купатила у односу на кухињу, што је довело до настанка римског купатила као засебног објекта. Специфично уобличавање просторије која је намењена купању у врелој води и презнојавању може се приметити код другог типа римских купатила, која су и даље интегрални део стамбене архитектуре. Купатила у објектима Casa del Labirinto у Помпеји и Villa della Pisanella у месту Боскореале, неки су од познатијих примера (сл. 2, где су калдаријуми означени сивим тоном). Овакво уобличавање калдаријума не би, међутим, требало посматрати као стриктно правило. Посматрано на широј територији Римског царства, план калдаријума је био подложан варијацијама, које су посебно биле изражене код већих купатила. Пре свега, овај тип основе је био чест код купатила са мањом површином, које ћемо у овом раду називати мања римска купатила. ${ }^{5}$ Исти тип основе калдаријума најчешћи је био и у појединим термалним објектима на тлу источне и јужне Србије.

\section{Уобичајени облици калдаријума римских купатила}

Примери из првог века п. н. е., попут оних из Помпеје, дочаравају уобичајене облике основа калдаријума у низу топлих просторија купатила на тлу Римског царства, па је у литератури указано да се код једног броја ових купатила може препознати специфичан план просторије намењене купању у врелој води (Krencker et al. 1929, 181-182, abb. 241a). Овај препознатљиви план је регистрован кроз читав период позне антике са мањим варијацијама (сл. 3). Кренкерова теза са почетка 20. века у последњих тридесет

\footnotetext{
${ }^{5}$ Према И. Нилсен, купатила површине до $500 \mathrm{~m}^{2}$ дефинисана су као тзв. балнеуми који се, осим према димензијама, од много већих терми разликују по мањој опремљености, са сведенијим системом инсталација и скромнијој декорацији. Још једна од теза Нилсенове је да су балнеуми били приватне грађевине, док су велике терме финансирали цар, држава и богате локалне заједнице. На поједине недостатке теорије И. Нилсен упозорили су Делејн и Фаган, посебно кад је реч о критеријумима граничне површине и степена опремљености у различитим деловима Римског царства (DeLaine 1993: 348-349; Fagan 1993: 61-68). Наиме, критеријум разврставања купатила на она чија је површина испод 500 м $^{2}$ и она са већом површином не разјашњава проблем доградње појединих мањих купатила, тј. да ли се она у првој фази посматрају као балнеуми, а потом као терме, када се доградњом премаши $500 \mathrm{~m}^{2}$. Јегул је упозорио да по питању термина терми и балнеума Римљанима није била битна подела на право коришћења, односно на приватна и јавна купатила (Yegül 1992: 172-185; Nielsen $1993,120)$. Проблемима терминологије, било да је реч о термама и балнеумима, било да је реч о засебним просторијама, посебно се у последње време бавила С. Марешал (Maréchal 2015: 140, са старијом литературом). Имајући у виду да претходни аутори оправдано указују на проблем навођења термина балнеума и терми, у нашем раду ћемо се пре свега служити општијим термином купатила.
} 

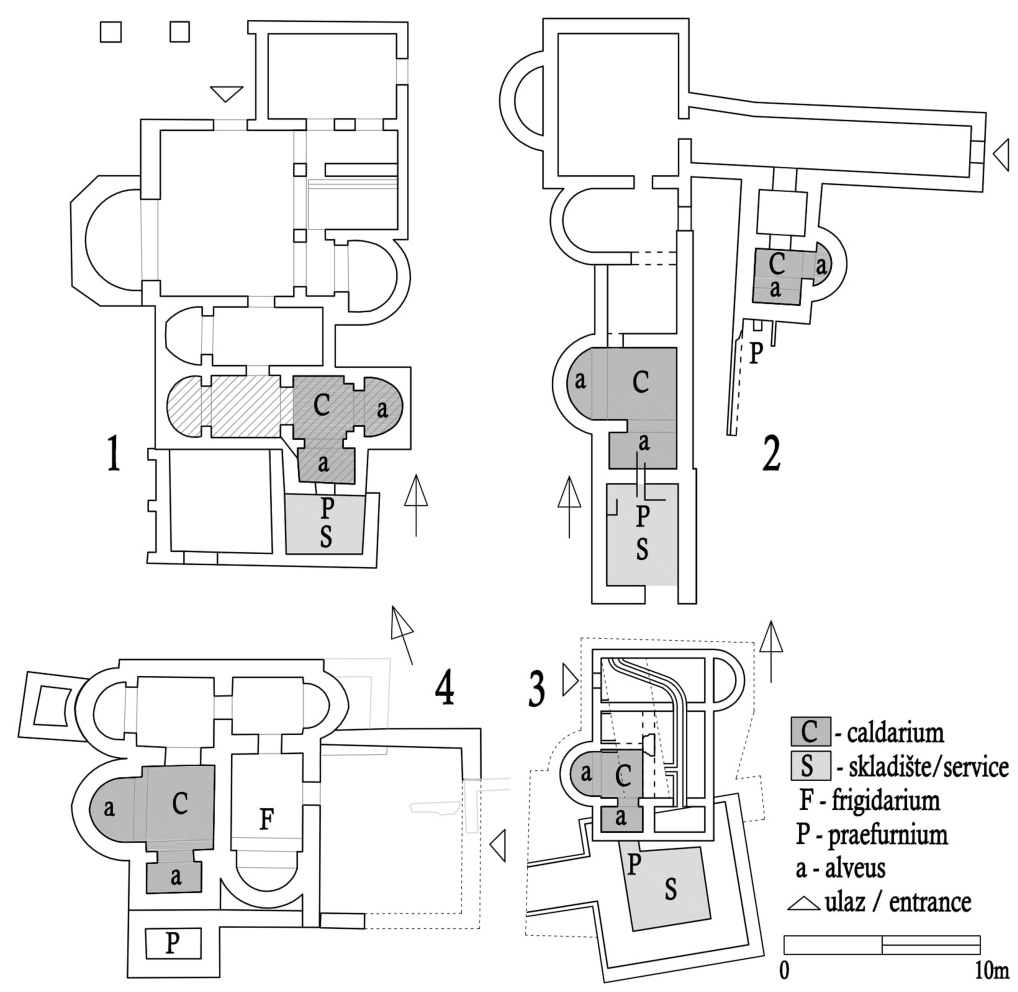

Сл. 4. Основе појединих купатила у источној Србији: 1. Ромулијана (аутор, према Čanak-Medić, Stojković-Pavelka 2010, 100); 2. Талијата (Petrović, Vasić 1996, 26; модификован цртеж, према аутору); 3. Поречка река (Petrović 1984,

289; модификован цртеж, према аутору); 4. Тимакум Минус код Равне (према Бјелић 2020, 154, sl. 4)

Fig. 4. Plans of certain baths in eastern and southern Serbia: 1. Romuliana (by the author, according to Čanak-Medić, Stojković-Pavelka 2010, 100); 2. Taliata (Petrović, Vasić 1996, 26; modified drawing, according to the author); 3. Porečka Reka (Petrović 1984, 289; modified drawing, according to the author); 4. Timacum Minus near Ravna (according to Bjelić 2020, 154, fig. 4)

година оснажена је навођењем бројних примера са целе територије Римског царства (Yegül 1992, 51). ${ }^{6}$

Према овим тезама, калдаријум се одликује централним простором правоугаоног облика са посебним проширењима (анексима) на барем двема суседним странама. Прво проширење има облик широке нише правоугаоне

${ }^{6}$ Описани план централног типа калдаријума може се пратити до крајњих граница царства од Виндоланде (данашња Британија) до Тимгада (Алжир), и од Конимбриге (Португалија) до Серђиле (Сирија) (Yegül 1992, фиг. 49-50, 278, 268, 280-281, 411). 
основе, уз чију се спољну страну надовезује конструкција ложишта са дебљим или удвојеним зидовима, док је друго проширење у виду конхе. Поред ова два, најчешћа проширења, на свакој од преосталих страна калдаријума може постојати и још по једно, у оба наведена облика основе. ${ }^{7}$ У сваком анексу била је смештена по једна када, односно алвеус у виду базена.

Неколико фактора је утицало на специфичан положај калдаријума у купатилима. Калдаријум је по свом положају најудаљенији од улаза у објекат, док је фригидаријум најближи улазу. Овакав редослед просторија диктирао је крајње практичан разлог: калдаријуми су удаљени од улаза како би се избегао пад температуре и одржао ниво влажности, док су фригидаријуми били ближе улазу због потребе да се, као хладне просторије, директно проветравају и брже хладе.

Још једна околност је утицала на праксу да код римских купатила топле просторије буду даље од улаза: положај префурнијума. Због ложења ватре у префурнијумима калдаријума, у том делу објекта је било дима. Осим наведеног, руковање дрвном грађом или угљем (ћумуром) фактори су због којих се страна објекта са префурнијумом дефинисала као „прљава” у данашњем смислу те речи. Како би се избегао неугодан контакт корисника купатила са овом страном, приступ купатилима био је на супротној „чистијој” страни објекта. Не треба искључити ни избегавање могућности да се укрштају путање оних који опслужују ложишта (радници, слуге и робови) и путање корисника купатила. Сумирањем изложених околности закључујемо да су на карактеристичан положај калдаријума утицали следећи фактори: његова препознатљива основа са алвеусима ван централног правоугаоног простора; потреба да се префурнијуму калдаријума приступа директно споља; потреба да ова просторија буде што даље од улаза. Калдаријуми се зато најчешће могу препознати у угловима основе купатила кад је реч о блоковском распореду, или на крају путање кад је реч о распореду просторија у низу. ${ }^{8}$

Тик уз калдаријум налазили су се тепидаријуми, још једна врста топлих просторија. Као и претходне, и ове просторије могле су бити опремљене кадама, које су на тлу јужне и источне Србије најчешће полукру-

\footnotetext{
${ }^{7}$ Прегледом примера може се утврдити да су оваква решења заступљенија код калдаријума нешто веће површине.

${ }^{8}$ Купатила са распоредом просторија у једном низу одликују се одајама распоређеним линеарно према функцији и градацији температуре приликом купања, тако да је путања корисника на једном правцу. Блоковски распоред се одликује паралелним редовима просторија, тако да је корисник често условљен цикличном путањом кретања. Основну типологију дао је Кренкер, а прихватили су је Нилсен и Јегул. (Krencker et al. 1929: 177-181, abb. 234-240; Yegül 1992: fig.142; Nielsen 1993: fig.1).
} 
жног облика. Тепидаријуми се разликују од калдаријума по томе што су ови први загревани посредно, и били су слабије опремљени кадама и специјалним инсталацијама. Посредно загревање тепидаријума значи да се ложишта нису увек налазила непосредно уз њих. Слабија опремљеност препознаје се по мањем броју када. Обично није било алвеуса или је постојао само један, док су калдаријуми нешто мањих купатила имали бар два. У склопу топлих просторија налазили су се и лаконикуми и судаторијуми. Ове одаје биле су намењене презнојавању, и то на два начина. Први начин је суво презнојавање, односно боравак у просторији са загрејаним подом и зидовима, у којој нема влаге. Презнојавање на други начин постизало се просипањем воде у претходно загрејаној просторији. У зависности од тога који се од ових начина примењивао, Витрувије разликује лаконикум намењен сувом презнојавању и судаторијум намењен презнојавању у влажном простору (Vitruvius 1990, V, X, 116-117). Међутим, судећи по једном Сенекином наводу, та два термина су коришћена прилично слободно, што је у колоквијалном разговору међу Римљанима неретко доводило до њихове замене (Yegül 1995, 384).

\section{Калдаријуми римских купатила на тлу јужне и источне Србије}

Код разматраних римских купатила на тлу јужне и источне Србије не постоји канон по којем се одређивао непромењив распоред, број, опремљеност или облик тепидаријума, лаконикума и судаторијума. За разлику од наведених одаја, управо наведене карактеристике чине калдаријуме препознатљивим у низу топлих просторија.

Један од најстаријих до сада евидентираних примера римских купатила на тлу источне Србије налази се 100 м североисточно од утврђења Тимакум Минус (сл. 4.4). Припада римским војним купатилима која се налазе ван утврђења, али у њиховој релативној близини (Петровић, Васић, 1996, 26; Campbell, D. B. 2009. 52; Revell 2007: 235; Janković 2012, 31). Приликом скорије реинтерпретације резултата археолошких истраживања овог објекта (познатијег под називом „Терме I” у ранијој документацији и литератури), у југозападном углу објекта уочено је постојање просторије са описаним карактеристикама калдаријума. Раније је ова просторија била дефинисана као тепидаријум (Петровић, Јовановић 1997, 24. сл. 22; Janković 2012, 30, fig. 4). Међутим, њен облик, облик и положај када, удаљеност од улаза у купатило, непосредна близина префурнијума и заступљене структуре недвосмислено коригују претходно одређење њене функције (Bjelić 2020, 155-156) и опредељују просторију као калдаријум. 
У калдаријум купатила на локалитету Тимакум Минус свакако се ступало из мање топле просторије са његове северне стране. Међутим, положај просторије калдаријума је неуобичајен, будући да се уз њен источни зид налази фригидаријум (сл. 4.4), што је условљено градитељским концептом сажетог блоковског распореда просторија римског купатила у првој фази, који је убрзо показао и своје мане у практичној примени. Међусобна близина ове две просторије неповољно је деловала и на фригидаријум и на калдаријум, што је довело до накнадне интервенције у другој фази постојања купатила (Bjelić 2020, 156-157). С обзиром на датовање објекта у 3. век, наведени пример калдаријума био би један од најстаријих регистрованих на тлу источне Србије са препознатљивим планом за ову просторију. Положај калдаријума уз фригидаријум у Тимакум Минусу засад је усамљени пример овакве праксе на поменутом простору, јер се не може приметити у плановима осталих млађих римских купатила. У окружењу, одређене сличности по питању величине и распореда склопа постоје код купатила Виле 1 у Монтани из друге половине 2. века, Бугарска (сл. 8.3). ${ }^{9}$

У источној Србији постоји још један пример купатила у близини утврђења, где је затечен калдаријум. У питању је војно купатило Талијате, чије су просторије за купање распоређене у низу (Петровић, Васић 1996, 26). Купатило се одликује групом већих просторија за купање на западној страни и групом мањих на источној (сл. 4.2). Унутар западне групације разликују се јужна, средишња и северна просторија. На северну просторију надовезује се са њене источне стране просторија издужене основе. На средини јужног зида ове просторије надовезује се источна групација која делује као накнадно придодата комплексу римског купатила. По једна просторија унутар обе наведене групе одликује се већ описаним планом калдаријума. Јужно од ових просторија налазе се ложишта.

У појединим римским купатилима откривен је сложенији распоред топлих просторија у низу, док су остале просторије пројектоване испред њих. Оваква купатила регистрована су на тлу јужне Србије у Медијани, Бацу и Жујинцу (сл. 5.1-5.3). Међутим, овакав распоред просторија је био чест и у окружењу, што се може видети на другим примерима у данашњој Србији, Северној Македонији, Бугарској и Хрватској, у које спадају купатило у Чачку (3-4. век), Мансију Идимум (4. век), Губеревцу (3-4. век), Бељини (4-5. век), Стобију (4-5. век), Никополису ад Нестуму (4. век), Лудбрегу (4. век) и др. Код њих се може приметити наведено правило да је калдаријум

\footnotetext{
9 Примери зидања калдаријума непосредно поред фригидаријума и у окружењу су ретки. Један од примера регистрован је у Хистрији у Румунији (Suceveanu 1982, Fig. 46).
} 

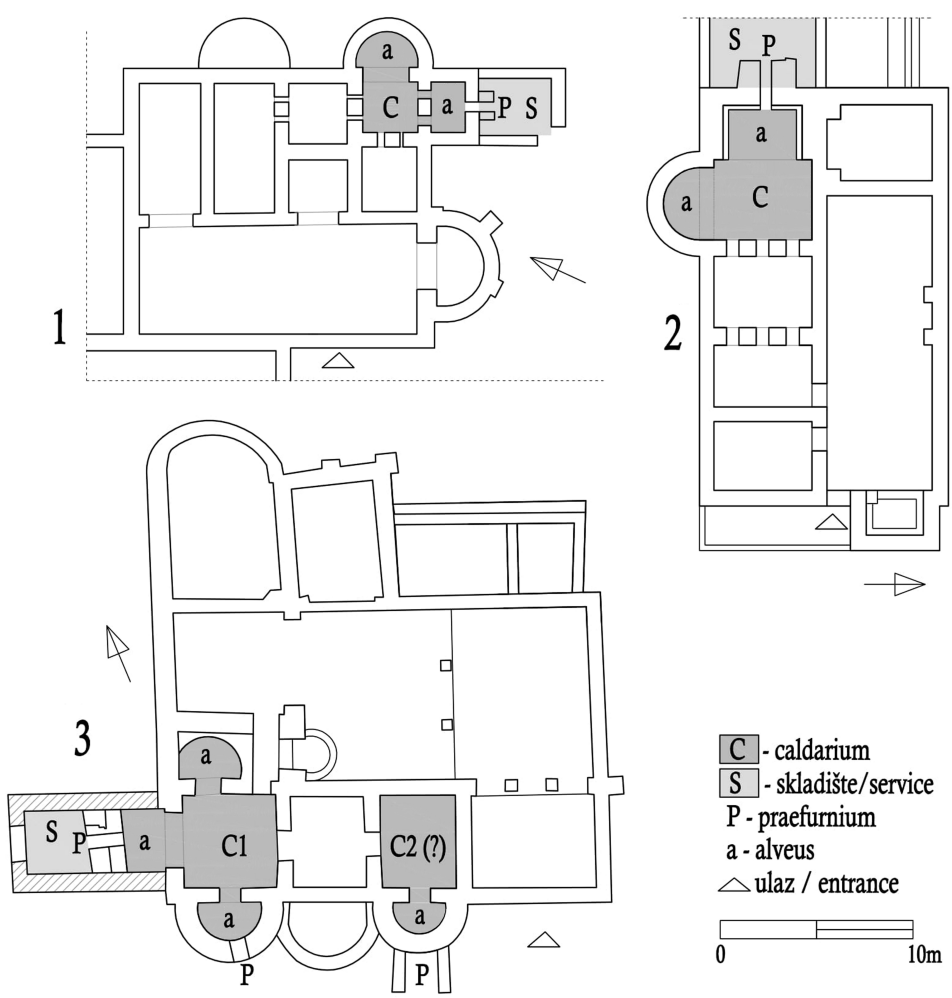

Сл. 5. Основе појединих купатила у јужној Србији: 1. Жујинци (аутор, према Tomović et al. 2005, 322); 2. Баце (аутор, према Jordović 1999, 198. sl. 1);

3. Медијана (Petrović 1994, 34; модификован цртеж, према аутору)

Fig. 5. Plans of certain baths in eastern and southern Serbia: 1. Žujinci (by the author, according to Tomović et al. 2005, 322); 2. Bace (by the author, according to Jordović 1999, 198. fig. 1); 3. Mediana (Petrović 1994, 34; modified drawing, according to the author)

смештен што даље од улаза у објекат, а углавном се налази у угаоном делу, увек уз припадајући префурнијум.

Археолошким истраживањима у Жујинцу почетком овог столећа откривено је римско купатило сложене структуре (сл. 5.1). Истраживањима је откривено десет просторија, али је закључено да је објекат могао бити и веће површине јер се остаци шире ка северу и западу. Према археолошким налазима купатило је датовано у 4. век (Булатовић, Капуран 2004/5, 124-125). Просторија која има описане карактеристике калдаријума налази се на југоисточној страни објекта, а старији истраживачи су је претходно већ идентификовали као калдаријум (Томовић, Булатовић и Капуран 2005, 341). Ложиште калдаријума (тј. његов префурнијум) налази се у засебној просторији. 
Купатило код села Баце има правоугаону основу која је подужним унутрашњим зидом подељена на северну и јужну половину (сл. 5.2). Три просторије постављене у низу на јужној половини основе имале су хипокаусте међусобно спојене каналима. За све три просторије је раније било наведено да представљају калдаријуме (Јордовић 1999, 197). Међутим, по облику основе и положају једино она у југозападном делу купатила поседује архитектонске карактеристике према којима би јој се могао приписати наведени назив. Остале просторије немају ни каде ни префурнијуме.

Калдаријуми са по три алвеуса су на простору јужне и источне Сpбије регистровани и код римских купатила нешто веће површине, чији је карактеристичан представник објекат на Медијани (сл. 5.3). У овом купатилу постоје три просторије које поседују хипокауст, окренуте су ка јужној страни и претходно су све биле дефинисане као калдаријуми (П. Петровић 1994, 34). При томе је остављена могућност да је просторија на источној страни ове скупине могла представљати судаторијум. Препозната је околност да је првобитни префурнијум уз полукружну каду западне просторије зазидан, након чега је префурнијум пребачен уз каду источне просторије (Дрча 2006, 15). Током истраживања 2019. године откривен је још један префурнијум са правоугаоном кадом уз западну страну западне просторије. ${ }^{10}$ Будући да је ова када са припадајућим префурнијумом била у западној просторији, та просторија се, заједно с кадом, дефинише као калдаријум. Положај каде и префурнијум накнадно су одређени на делу простора који је претходно оивичен зидовима друге просторије (можда старијег објекта; ови зидови су на сл. 5.3 означени косом шрафуром), која се простирала југозападно од топлих просторија римског купатила. ${ }^{11}$

Калдаријум купатила на Медијани, поред каде и припадајућег префурнијума на западној страни, карактерише још по један полукружни ба-

\footnotetext{
${ }^{10}$ Нажалост, темељи калдаријума су президани приликом конзервације која је спроведена 1967, тако да данас западни алвеус не делује као њихов саставни део. Детаљније анализе ове просторије, префурнијума и алвеуса калдаријума биће објављене у извештају који третрира резулате археолошких ископавања током 2019. године.

${ }^{11}$ Та просторија је била позната и приликом првих ископавања овог купатила на Медијани, што се може видети према старом плану који је објавио Адам Оршић Славетић (Оршић Славетић 1933-1934, 308, сл. 7). План ове просторије на Медијани и положај префурнијума и каде купатила на делу њеног простора указују да је просторија (старијег објекта?) придружена новом склопу купатила и да је ложиште било покривено кровном конструкцијом наведене просторије, док је када била саставни део простора западне просторије. Као што се претпостављало и на основу ранијих истраживања, систем подног и зидног грејања очигледно је престао да функционише у неком тренутку, након чега је дошло до накнадног измештања и прислањања новог префурнијума уз полукружну каду источне просторије. Могуће је да је тада дошло до промене приликом које је западна просторија (C1 на нашој сл. 5.3) изгубила функцију калдаријума, а источна просторија (C2) преузела функцију новог калдаријума, али та претпоставка мора остати у домену даљих анализа.
} 

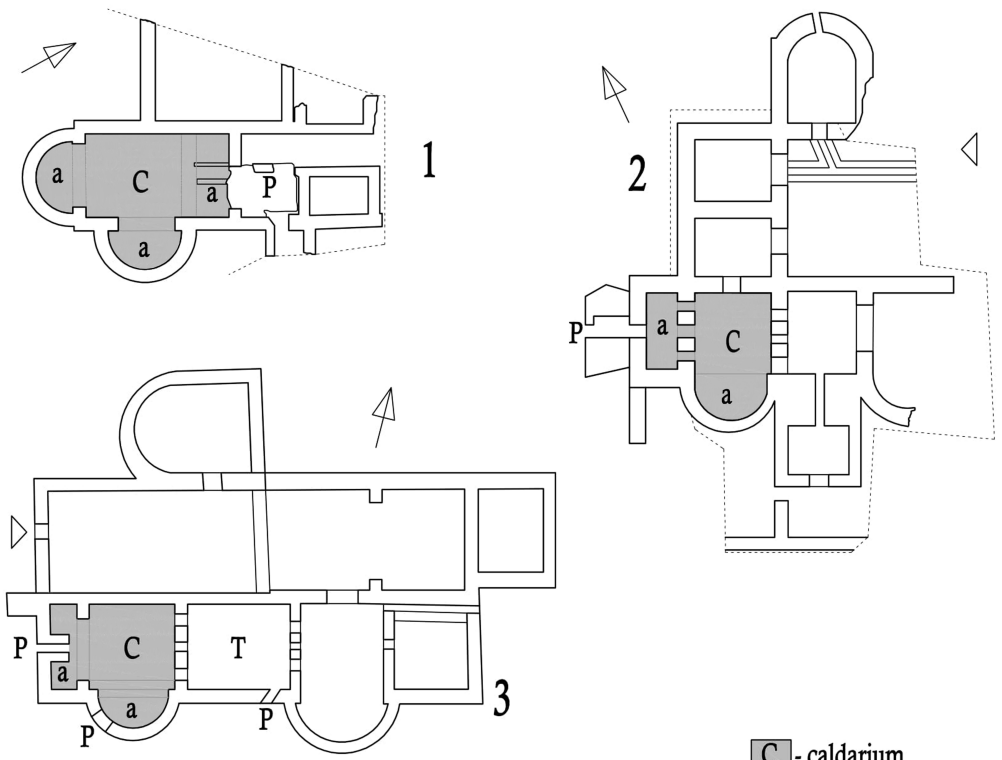

C- caldarium

S - skladište/service

$P$ - praefurnium

a - alveus

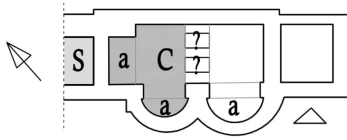

4

Сл. 6. Основе појединих купатила у осталим деловима Србије: 1. Београд Сингидунум (аутор, према Бојовић 1977, 7); 2. Чачак (аутор, према Јеремић, Гојгић 2012, сл. 7); 3. Мансио Идимум (аутор, према Vasić, Milošević 2000, 52,

sl. 13); 4. Муниципио ДД - Сочаница (Чершков 1970, 51, слика 3; модификован цртеж, према аутору)

Fig. 6. Plans of certain small baths in other parts of Serbia: 1. Belgrade - Singidunum (by the author, according to Bojović 1977, 7); 2. Čačak (by the author, according to Jeremić, Gojgić 2012, fig. 7); 3. Mansio Idimum (by the author, according to Vasić, Milošević 2000, 52, fig. 13); 4. Municipio DD - Sočanica (Čerškov 1970, 51, fig. 3; modified drawing, according to the author)

зен на северној и јужној страни. Према овој карактеристици, калдаријум на Медијани је нешто опремљенији од осталих у јужној и источној Србији, али слични примери калдаријума са три каде могу се регистровати и у окружењу. Сличан план основе калдаријума са три каде може се приметити и у купатилу градске виле у Сирмијуму (сл. 7.5) и Монтани (сл. 8.2), док је нешто другачији план са три каде забележен у купатилу у Сингидунуму, на простору садашњег студентског парка (сл. 6.1), у Баргали (сл. 7.1) и Стобију (сл. 8.4). 

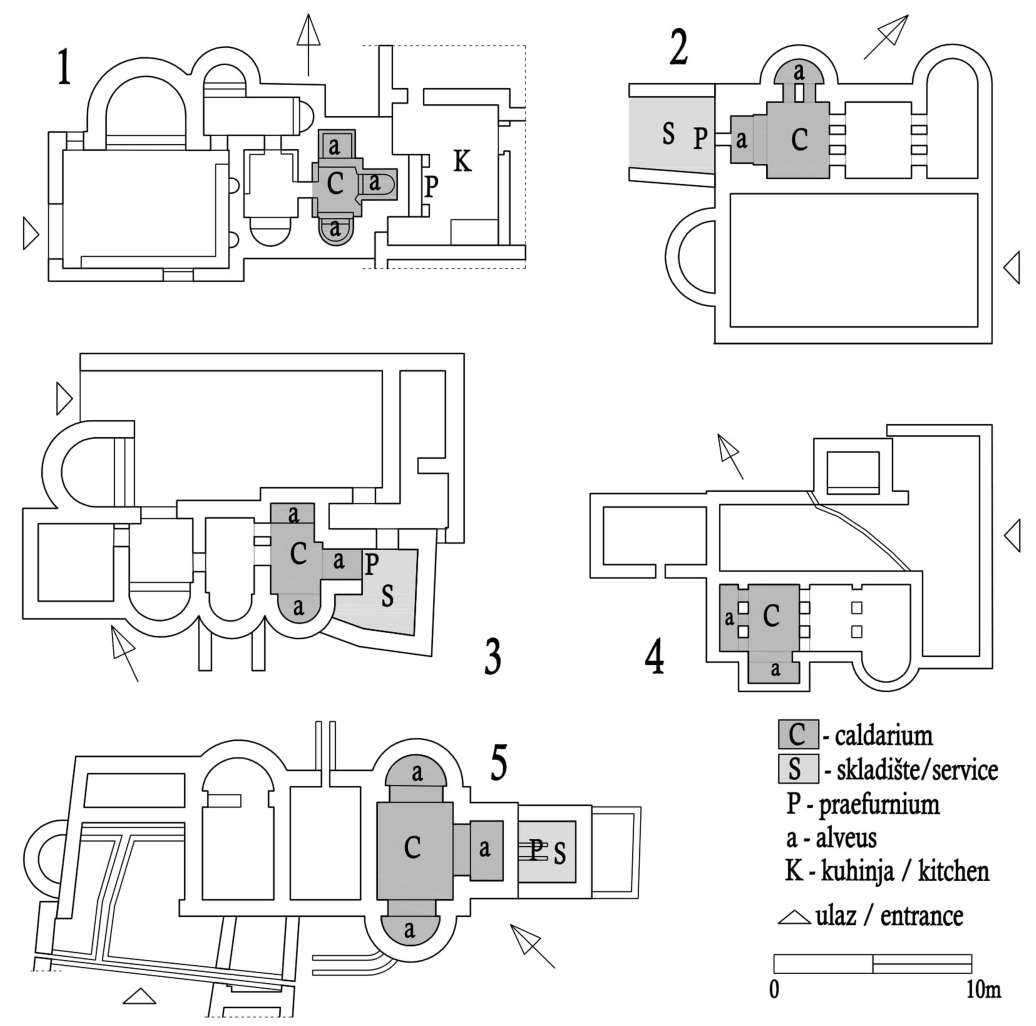

Сл. 7. Основе појединих купатила у осталим деловима Србије и у Северној Македонији: 1. Баргала (аутор, према Белдедовски, Нацев 2006, пл. 1); 2. Губеревац-Прутен (аутор, према Величковић 1958, сл. 3); 3. Бељина (аутор, према Васић 1983, пл. 2); 4. Стоби, мале терме (аутор, према Талевски 2018, сл. 2); 5. Сирмијум, локалитет 4: вила урбана (аутор, према Parović-Pešikan 1969, sl. 1)

Fig. 7. Plans of certain small baths in other parts of Serbia and in Northern Macedonia: 1. Bargala (by the author, according to Beldedovski, Nacev 2006, pl. 1); 2. Guberevac - Pruten (by the author, according to Veličković 1958, fig. 3); 3. Beljina (by the author, according to Vasić 1983, pl. 2); 4. Stobi, small baths (by the author, according to Talevski 2018, Fig. 2); 5. Sirmium, site 4: villa urbana (by the author, according to Parović-Pešikan 1969, Fig. 1)

Приликом истраживања римског купатила у Ромулијани (сл. 4.1) констатовано је постојање просторије на јужној страни објекта (на нашем цртежу означена косом шрафуром), коју су истраживачи определили као калдаријум (Чанак-Медић, Стојковић-Павелка 2010, 100, 102, План XLIII). Међутим, мислимо да је само источни део основе раније назначене просторије могао имати ову функцију, а да се њен западни део грејао само посредно преко канала у зиду којим су овај и источни део просторије били раздво- 

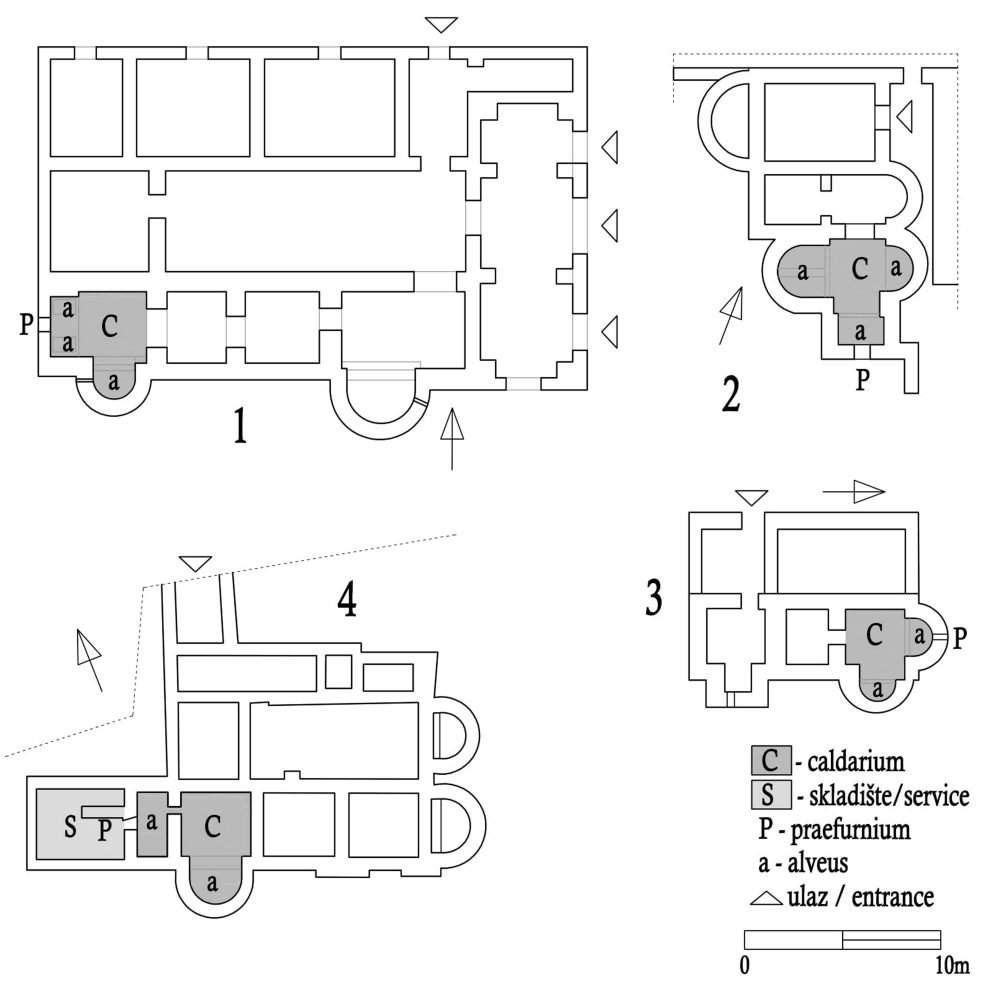

Сл. 8. Основе појединих купатила у Бугарској и Хрватској: 1. Никополис ад Нестум (аутор, према Petrova, S. 2012. 319); 2. Монтана, Вила 2 (аутор, према Ivanov, Luka 2018, 247-248); 3. Монтана, Вила 1 (аутор, према Ivanov, Luka 2018, 247-248); 4. Лудбрег - Iovia (аутор, према сателитском снимку са сајта Google Earth)

Fig. 8. Plans of certain small baths in other parts of Bulgaria and Croatia: 1. Nicopolis ad Nestum (by the author, according to Petrova, S. 2012. 319); 2. Montana, villa 2 (by the author, according to Ivanov, Luka 2018, 247-248); 3. Montana, villa 1 (by the author, according to Ivanov, Luka 2018, 247-248); 4. Ludberg - Iovia (by the author, according to a satellite image from Google Earth)

јени (према цртежу Улрике Р. Вулф у: Петковић 2010, 177; сл. 3.1). Источни део просторије има квадратну основу са полукружним базеном на источној страни и правоугаоном нишом на јужној страни, ка префурнијуму. Приступ овом делу просторије био је са јужне стране.

Крајем четвртог века долази до смањења интензитета грађења купатила на тлу источне и јужне Србије. За изградњу ове врсте објеката у том периоду је иначе на широј територији неретко коришћен грађевински материјал појединих напуштених утврђења, односно остаци грађевина кроз њихову 
пренамену. Пример такве праксе у источној Србији је и купатило скромних димензија у Поречкој реци, изграђено у време цара Валентинијана (Петровић 1982-1983, 286-288). Објекат је изграђен на остацима бедема и једне од кула некадашњег утврђења (сл. 4.3). Југозападна просторија унутар објекта је била идентификована као тепидаријум (Петровић 1982-1983, 288, Janković 2012, 30, fig. 5). Међутим, према облику основе и положају у склопу купатила, она пре може бити дефинисана као калдаријум. На плану се примећује да је калдаријум малих димензија, али пропорционалан величини купатила. Сличне величине је и старији, али просторно ближи пример у групи мањих просторија у Талијати (сл. 4.2). У окружењу, сличан облик и величину има калдаријум купатила у Муниципијуму DD (2-4. век, сл. 6.4.). Калдаријуму у Поречкој реци недостаје још једна када како би по величини и просторној организацији био сличан калдаријумима у Баргали (сл. 7.1), купатилу у Вили 1 код Монтане (сл. 8.3) и у малом купатилу у Стобима (сл. 8.4). Очигледно је да просторна структура калдаријума купатила на тлу јужне и источне Србије до краја касне антике прати решења која су присутна и у окружењу.

\section{Грејање калдаријума}

Поред разматраних архитектонских карактеристика калдаријума постоје и оне које се пре могу посматрати са грађевинског аспекта. Степен усклађености разнородних инсталација и архитектонско-грађевинских елемената какав је присутан у калдаријумима, не може се приметити не само у осталим просторијама купатила него ни код других објеката римске архитектуре. Будући да је основна функција калдаријума купање и боравак у простору са изузетно високим температурама, анализе конструкција потребне за загревање ваздуха и воде у овим просторијама од посебног су значаја.

Од античких префурнијума, односно ложишта купатила, најчешће су данас преостала само по два паралелна зида о које су се ослањали њихови сводови, покривајући их ради заштите од падавина.

Загревање хипокауста није било континуирани процес, већ су се ложишта палила онда када је за грејањем постојала потреба. Пошто су потребе за тим у термалним објектима поприлично честе, то је доводило до честих паљења ложишта, односно грејања и хлађења, како самих система подног и зидног грејања, тако и околних зидних конструкција. Услед изражених температурних осцилација најугроженије су биле конструкције префурнијума. Овакве осцилације могле су изазвати пукотине у зидној маси. То је један од разлога што се у изградњи префурнијума, а пре свега њихових сводова, више користила опека као материјал који подноси температурне 
осцилације боље него камен,. Вероватно из истог разлога ојачаване су зидне масе између када и префурнијума, и то повећањем дебљине зидова у делу префурнијума или дилатацијом између зидова префурнијума и зидова уз које се налазе. Споменуте интервенције у купатилима на тлу јужне и источне Србије могу се приметити код префурнијума у Тимакум Минусу (дилатација између зидова - сл. 4.4), Жујинцу (дилатација између зидова - сл. 5.1), у Бацу (задебљање зидова - сл. 5.2) и у Медијани (дилатација између зидова и задебљање зидова - сл. 5.3). Што се тиче раније поменутих купатила у окружењу, ојачања зидова су констатована у Мансију Идимум (сл. 6.2), у Муниципијуму DD (сл. 6.4), Баргали (сл. 7.1), Губеревцу (сл. 7.2), Никополису ад Нестуму (сл. 8.1). ${ }^{12}$

У континенталним деловима Европе, где обилне падавине нису биле реткост, постојала је опасност да веће количине горивог материјала кисну. Неопходна је била заштита горивог материјала и префурнијума од атмосферилија. Зато су префурнијуми били део посебних просторија у којима је складиштено дрво или угаљ (ћумур), чији се зидови ослањају на калдаријуме, тј. њихове алвеусе. (Yegül 1992, 371-372). Ове просторије, на нашим сликама означене светлосивим тоном, могу се препознати у Ромулијани (сл. 4.1), Талијати (сл. 4.2), Жујинцу (сл. 5.1), Бацу (сл. 5.2), Медијани (сл. 5.3), али и у Сингидунуму (сл. 6.1), Муниципијуму DD (сл. 6.4), Баргали (сл. 7.1), Губеревцу (сл. 7.2), Стобију (сл. 7.4), Сирмијуму (сл. 7.5). Наткривањем ових просторија, и резервоари и бојлери били су заштићени од наслага лишћа и утицаја животиња (пре свега глодара, гмизаваца и птица) на квалитет воде. За прављење такве просторије са префурнијумом, уз већ поменуто купатило у Поречкој реци, искоришћена је унутрашњост старе куле (Петровић 1982-1983, 288).

Међутим, најстарији примери из Италије указују на још једну функцију споменутих просторија, која је код нас још увек недовољно испитана. Формирање кухиње уз префурнијуме калдаријума терми било је често, али и веома практично (Yegül 1992, 50-54). Већу количину горива којом су загревани префурнијуми, било је практично искористити и за ложење приликом термичке обраде хране. При томе, приступи калдаријумима и кухињама били

\footnotetext{
12 Поред температурних осцилација постојали су и додатни разлози за зидање дебљих зидова префурнијума у поређењу са осталим зидовима. Велике количине воде у бојлерима захтевале су формирање додатног простора са спољне стране алвеуса калдаријума, па се тај простор обично правио на зидовима довољно јаким да носе велики бојлер. Поред тога, најстарији примери из римског света указују да се вода сакупљала у посебним резервоарима пре него што би дошла до бојлера у којима се потом загревала (Yegül 1992, 373-374). Простор за резервоаре или бојлере најчешће је прављен изнад темена свода самих префурнијума (Bouet 2003, fig. 38).
} 
су свакако одвојени. Зато је веома индикативан пример купатила у Баргали, где је кухиња изграђена управо уз префурнијум калдаријума код купатила (сл. 7.1) (Белдедовски, Нацев 2006, 296-298; Белдедовски 2008, 367-369).

Примери купатила на тлу јужне и источне Србије указују да су њихови хипокаусти били израђени на уобичајени начин - применом стубића од опека распоређеним на међусобно правилном размаку (суспензура). На њима је био постављен један до два реда опека већих димензија (бипедала), преко којих је изведен под у слојевима малтера, са различитим завршним обрадама. Хипокауст калдаријума је био омеђен зидовима са свих страна осим на месту где су врели гасови улазили из префурнијума и тамо где је топао гас пролазио даље из калдаријума ка тепидаријуму. Ова места била су изведена у виду засвођених канала. Хипокаусти су у калдаријумима редовно заузимали комплетан простор супструкције поднице тако да се налазе и испод алвеуса, односно каде за врело купање.

За завршну обраду пода централног простора у калдаријуму могле су се користити плоче од обичног камена, или у случају луксузнијих купатила, мермерне плоче или чак мозаик. Међутим, на тлу источне и јужне Србије, па и шире нема очуваних трагова подова централног простора калдаријума код регистрованих примера, тако да се ништа прецизније не може рећи. Нешто су боље очувани подови алвеуса, и то у калдаријуму купатила у Бацу. Израђени су од дебелог слоја хидрауличног малтера. Подове алвеуса од подова централног простора раздвајају ниски зидићи. На истој висини ових зидића су и зидане клупе уз бочне зидове оба алвеуса. Подница од хидрауличног малтера присутна је и у базену калдаријума у Ромулијани (Чанак-Медић, Стојковић-Павелка 2010, 102).

Систем зидног грејања истражених купатила на тлу јужне и источне Србије био је састављен од вертикалних димоводних канала као што је то случај у многим калдаријумима широм Римског царства. Постоје различити трагови елемената конструкције канала и облоге зидова, односно тегуле мамате, тубулуси и калемови са Т-клиновима који носе оплату. Налази тегула мамата су на тлу источне и јужне Србије ретки и поуздано су регистровани једино на простору купатила у Тимакум Минусу. Међутим, већина фрагментарних примерака затечена је у супструкцији пода накнадно дозиданог аподитеријума овог купатила (Bjelić 2020, 153, са напоменом 53). Основано се може претпоставити да су се оне ту нашле у шуту којим је нивелисан терен за изградњу нове просторије. Будући да се око купатила у Тимакум Минусу наишло на још неколико примерака, извесно је да су тегуле мамате биле део опреме зидног грејања у првој фази функционисања овог објекта 

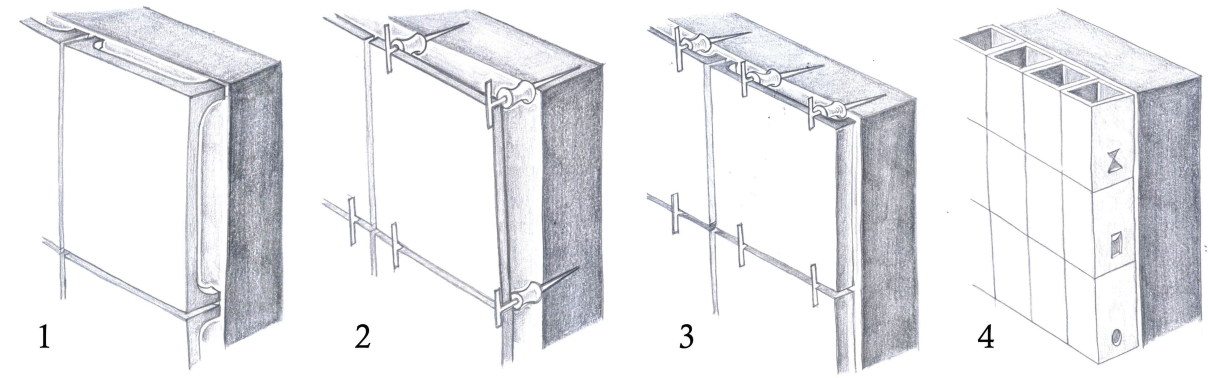

Сл. 9. Решења зидног грејања помоћу елемената присутних у калдаријумима купатила на тлу јужне и источне Србије употребом: 1. тегула мамата;

2. мермерних плоча, Т-ексера и калемова; 3. претпостављено решење употребом црепова, Т-ексера и калемова; 4. употребом тубулуса (цртежи аутора)

Fig. 9. Wall heating solutions with the use of elements present in caldaria of baths in southern and eastern Serbia, by using: 1. tegulae mammatae; 2. marble slabs, T-nails, and terracotta spacers; 3 . hypothetical solution with tiles, T-nails and terracotta spacers; 4. tubulii (drawings by the author)

(сл. 9.1). Након оштећења зидног грејања, тегуле мамате су вероватно приликом обнове и доградње у другој фази биле замењене опекарским калемовима и већим Т-клиновима ${ }^{13}$ (Bjelić 2020, 151), који су затечени и у склопу осталих купатила, изграђених крајем 3. и почетком 4. века на југу и истоку данашње Србије. Слични примерци тегула мамата су констатовани и код купатила у Чачку, као и други наведени елементи зидног грејања (Јеремић, Гојгић 2012, 41).

Појава опекарских калемова и Т-клинова регистрована је у већини терми на тлу источне и јужне Србије (у Тимакум Минусу, Медијани, у Бацу и Жујинцу). Код репрезентативнијих примера купатила, какви су свакако у Медијани и Ромулијани, за облагање зидова коришћене су мермерне плоче које су се ослањале о Т-клинове, провучене кроз опекарске калемове (сл. 9.2). Међутим, мермер као квалитетан материјал за зидну оплату није био доступан свим слојевима друштва који су инвестирали у изградњу купатила. Код једног броја купатила приметан је изостанак ових плоча, а примере представљају купатила у Тимакум Минусу, Бацу, Жујинцу. У релевантној литератури која се бави купатилима на тлу Србије до сада није објашњено како би уз присуство калемова и Т-клинова и истовремени изостанак мермерних плоча функционисало зидно грејање. Недостатак in situ очуваних решења главни је узрок томе. Међутим, овде бисмо као једно од решења

\footnotetext{
${ }^{13}$ Врх калемова је био укуцан у основну зидну масу, а глава у виду хоризонталне пречке служила је за ношење самих плоча.
} 
могли да понудимо усправно постављање црепова (сл. 9.3) које су још стари Грци применили за зидно грејање у својим купатилима, а примењивало се и у столећима римске превласти (Fournet, Redon 2013, 249-251, 255-256). Црепови свакако нису били скупљи него мермер, а њихова површина и број могли су задовољити потребну квадратуру зидова. За ослањање, као и за мермерне плоче, били су коришћени Т-клинови и опекарски калемови. На примену црепова у комбинацији са глиненим калемовима и Т-клиновима указује и пример зидног грејања у калдаријуму купатила у хронолошки и територијално ближој Баргали (Белдедовски, Нацев 2006, 296).

Од посебног значаја су и случајеви у којима су регистровани тубулуси, грађевински елементи који се примарно везују за зидно грејање (сл. 9.4). Међутим, њихово присуство у купатилима на тлу источне и јужне Србије је веома ретко. У in situ стању су регистровани само у Ромулијани уза зид правоугаоног проширења калдаријума ка префурнијуму. Први истраживачи су зато претпоставили да је овај простор био судаторијум који је служио за презнојавање корисника (Чанак-Медић, Стојковић-Павелка 2010, 102). Међутим, под од дебелог слоја хидрауличног малтера на хипокаусту указује да је правоугаоно проширење послужило као када за вреле купке, односно алвеус калдаријума. Тубулус прислоњен уза зид на овом месту ишао би у прилог таквом тумачењу, јер би у том случају, поред подног грејања за доњи део каде, за одржавање температуре служило и зидно грејање. Грејањем алвеуса одоздо - преко пода, и са стране - преко зида, одржавана је највећа могућа температура воде у кади калдаријума, због чега је она примарно могла служити за вреле купке. У југоисточном делу простора калдаријума у Тимакум Минусу затечени су пали тубулуси (Bjelić 2020, 152). На другим местима, у склопу овог купатила затечене су и тегуле мамате као и опекарски калемови. Овакав просторни распоред наведених зидних елемената за грејање могао би да објасни постојање њихове три различите врсте у овом објекту. Сличан положај тубулуса констатован је у алвеусима калдаријума или обрушеним конструкцијама њихових зидова на просторе припадајућих префурнијума у купатилима Мансио Идимума, Ромулијане и Сингидунума (Васић, Милошевић 2000, 49, 281, Табла I - сл. 1; Чанак-Медић, Стојковић-Павелка 2010 , 102; Bojović 1977, 20).

Систем подног и зидног грејања римских купатила могао је у пракси бити тестиран тек након завршетка зидања носећих и покривних делова конструкције, па је његово планирање морало бити засновано на флексибилности (Taylor 2003, 87). У случају да систем хипокауста не функционише на жељени начин, није се могло у већој мери накнадно утицати на конструкци- 
је грејања везане за под или зид. Накнадне интервенције су подразумевале затварање једног префурнијума и отварање другог, најчешће у другој топлој просторији. Стара ложишта су обично била зазидана, што се на тлу Србије може видети на примерима купатила у Медијани, Тимакум Минусу, Виминацијуму (Nikolić et al. 2014), Чачку. На тај начин, друге просторије су могле добити функцију калдаријума са припадајућим кадама.

На бочним зидовима појединих алвеуса затечене су изливне оловне цеви или зидани канали у висини тик изнад равни подница када, којима је искоришћена вода отицала ван када. Изливне оловне цеви затечене су у Бацу и у Медијани (Дрча 2006, 16), док је зидани канал обложен малтером регистрован у базену источне конхе калдаријума у Ромулијани (Чанак-Медић, Стојковић-Павелка 2010, 102). Док у Бацу изливне цеви оба алвеуса воде ка поду централног простора, изливна цев конхе у Медијани води ка спољном простору купатила.

\section{Покривање калдаријума}

Калдаријуми су обично засвођени, али на тлу јужне и источне Србије међу регистрованим примерима купатила, а према записима и техничкој документацији са ранијих истраживања, нема очуваних остатака сводова. Међутим, боље очувани примери римских купатила указују на постојање сводова, пре свега изнад калдаријума, што је у сагласности са бољим одржавањем високе температуре и влажности у овим просторијама. Зидани сводови су омогућавали да се не изгуби велика количина топлоте преко површине кровног покривача, а без њих би и врели гасови погубно утицали на дрвену носећу конструкцију кровног покривача.

Климатске прилике на нашем тлу наметале су употребу кровног покривача. Његови остаци су поуздано утврђени на свим примерима наведеним у овом раду. Увек је реч о уобичајеној врсти римског кровног покривача сачињеног од тегула и имбрекса. Кровни покривач се могао ослањати на дрвену носећу конструкцију, а она на полеђину сводне површине. Ако грејања сводова није било, завршеци димоводних канала морали су се налазити на висини ослонаца сводова или веома близу те позиције (Yegül 1992, 366). Свако евентуално слегање зидних маса проузроковало би пукотине између зидова, ослонаца сводова, а затим и завршетака димоводних канала. То би отворило пут врелим гасовима за непосредан додир са дрвеном носећом конструкцијом кровног покривача. Да би се избегла та опасност, дрвене конструкције се извесно нису ни користиле за ослањање кровног покривача изнад топлих просторија купатила. Уместо њих, за ослањање кровног по- 
кривача могле су се наносити додатне количине зидне масе и малтера изнад темена сводова, а пре свега изнад ослонаца сводова, чиме би се постигла и већа стабилност сводова.

\section{Декорација калдаријума}

Декорисање ентеријера калдаријума подразумевало је примену различитих техника облагања зидова, подова, када и сводова. Од подова централног простора калдаријума у купатилима на тлу јужне и источне Србије нема очуваних примера. Подови и бочне стране када били су израђени од дебелих слојева хидрауличног малтера. Таква обрада је регистрована на оба алвеуса у калдаријуму у Бацу. Међутим, код луксузнијих купатила, преко хидрауличног малтера могле су бити постављене мермерне плоче, што је случај код алвеуса јужне конхе калдаријума у Медијани (Дрча 2006, 16). Нешто слично је урађено код алвеуса у калдаријуму купатила у Баргали, где су употребљене плоче од мање квалитетног камена (Белдедовски, Нацев 2006, 296).

Обрада површина алвеуса наводи на закључак да су и зидови осталих делова калдаријума услед изложености води и влази могли на исти начин бити покривени слојевима хидрауличног малтера. У зависности од степена обраде (луксуза), на зидовима је могла бити аплицирана мермерна оплата, за шта постоји могућност код калдаријума у Медијани (Zotović et al. 1967, 100). Због температурних промена и високог процента влажности у њима нису могле постојати зидне слике. Унутрашње површине сводова које су наткривале калдаријуме извесно су биле покривене хидрауличним малтером. Не постоје подаци који би за било који од евидентираних калдаријума указивали да су њихови зидови могли бити покривени мозаиком.

\section{Закључак}

Међу уобичајеним просторијама римских купатила, калдаријуми представљају свакако најспецифичније. Различите просторне комбинације облика у плану калдаријума, материјали, конструкције и инсталације, чине ове просторије веома занимљивим за истраживање.

Анализом домаће стручне литературе која третира објекте овог типа на тлу јужне и источне Србије, примећено је да калдаријуми често нису правилно или нису уопште идентификовани. Одређивање функције просторија код античких објеката на тлу Србије најчешће прате уобичајени проблеми као што је степен очуваности зидова који је углавном сведен на приземне и темељне зоне, или пак само на ове последње. Међутим, као један од разлога се може прихватити и непостојање јасних критеријума према којима се 
функција просторије опредељује. Из тог разлога су у овом раду приказани архитектонски критеријуми према којима би требало дефинисати и препознати просторије калдаријума приликом археолошких ископавања. Иако овај рад третира купатила на тлу источне и јужне Србије, надамо се да ће допринети бољој будућој идентификацији ове врсте просторија и у окружењу.

Најзначајније карактеристике анализираних калдаријума су облици и положај калдаријума у односу на остале просторије, приступ купатилу и његове инсталације. Основа калдаријума код разматраних римских купатила најчешће подразумева централни простор правоугаоне основе са припадајућим проширењима - анексима за каде у којима се корисник купа у врућој води, односно алвеусима. Каде које су непосредно ослоњене на префурнијум најчешће захтевају проширење правоугаоне основе, док су остале смештене у полукружним проширењима, тј. конхама. На тлу јужне и источне Србије калдаријуми имају прилично сличан и препознатљив облик, што би требало да буде први корак у покушају њиховог препознавања у основи купатила на овом простору. Калдаријум у римском купатилу најчешће је најудаљенији од улаза у низу топлих просторија, да би био ближе префурнијуму и да би се одржавала константна топлота и влажност. Из истог разлога ce, поред конструкције подног подразумева и зидно грејање, од којег се при археолошким ископавањима могу регистровати посебне врсте налаза као што су Т-клинови, тубулуси, калемови и тегуле мамате. ${ }^{14}$

На основу изложених критеријума могли смо да идентификујемо просторе каладаријума у купатилима тамо где они досад нису били поуздано идентификовани, односно у Бацу, Тимакум Минусу, Поречкој реци и Медијани. Поредећи калдаријуме појединачних купатила на тлу данашње јужне и источне Србије са онима у њеном блиском окружењу, могу се запазити сличности, пре свега у облику и положају те просторије у купатилима. Тиме се, уосталом, одликује и највећи број калдаријума у купатилима на тлу Римског царства.

Проблем идентификације калдаријума мора се посматрати сагледавањем свих расположивих података из различитих аспеката. Ако већина раније наведених карактеристика калдаријума може бити регистрована приликом археолошких истраживања специфичне просторије, могуће је поуздано тврдити да се ради о калдаријуму термалног објекта, који је иначе битан фактор идентификације функције целине римског термалног објекта. Као што смо поменули у раду, римско купатило се не може замислити без

\footnotetext{
${ }^{14}$ Они су, међутим, од секундарног значаја за идентификацију калдаријума, јер зидно грејање може постојати и код искључиво стамбених просторија.
} 
калдаријума. Када просторија са описаним карактеристикама у склопу целовито истраженог објекта није регистрована, велика је вероватноћа да се не ради о римском купатилу. Међутим, из овога се не сме изводити априори закључак да је постојање калдаријума довољан фактор за идентификовање целог објекта. Овде се пре свега мисли на случајеве у којима су калдаријуми, као део купатила, били интегрисани у план стамбених објеката.

\section{БИБЛИОГРАФИЈА}

Белдедовски, 3. Нацев, Т. 2006. Новооткриен термален објект во Баргала. Macedoniae acta archeologica 17: 289-302.

Biernacki, A., Klenina, E. 2016. The Labrum from the Large Legionary Bathhouse of Novae (Moesia Inferior). Archaeologia Bulgarica XX, no. 2: 45-56.

Bjelić, I. 2020. Block-type military balneum in Timacum Minus - Its spatial arrangement, social impacts, and architectural analogies. Starinar LXX: 145-172.

Bouet, A. 2003. Matériaux et techniques de construction, in Thermae Gallicae, Les Thermes De Barzan (Charente-Maritime) et Les Thermes Des Provinces Gauloises, ed. A. Bouet, 167-196. Bordeaux: Ausonius.

Bruneti, I., Bruneti M., Savić, M., 1967. Antički Rim: panorama jedne civilizacije (Tutto su Roma Antica), Beograd-Ljubljana: Prosveta, Mladinska knjiga.

Булатовић, А., Капуран, А. 2004/5. Заштитна ископавања локалитета на траси ауто-пута е-75 између Бујановца и Прешева 2003. године. Археолошки преглед 2/3: 124-125.

Васић, М., 1983. Римске терме у Бељини, Зборник радова Народног музеја 13, 5-16. Чачак: Народни музеј.

Vasić, M., Milošević G. 2000. Mansio Idimum, Rimska poštanska i putna stanica kod Medveđe, Beograd: Arheološki institut.

Vitruvius, 1912. Vitruvii de architectura libri decem. (ed. F. Krohn), Leipzig: Teubner.

Vitruvius, 1990. Deset knjiga o arhitekturi. Prevod i predgovor M. Lopac, Sarajevo: Svijetlost.

Величковић, М. 1958. Прилог проучавању римског рударског басена на Космају, у Зборник радова Народног музеја 1(1957-1958), 95-118. Београд: Народни музеј,

DeLaine, J. 1993. Roman Baths and Bathing. Journal of Roman Archaeology 6: 348-358. Дрча, С. 2006. Медијана. Ниш: Народни музеј Ниш.

Zotović, Lj., Petrović, N., Petrović, P. 1967. Niš - Mediana antičke terme. Arheološki pregled 9: 99-100.

Ivanov, R., Luka, K. 2018. Montana - Praesidium, Regio, Municipium, in: Roman cities in Bulgaria, ed. R. Ivanov. T. 2, 197-278. Sofia: Prof. Marin Drinov Academic Publishing House.

Janković, M. 2012. The Social Role of Roman Baths in the Province of Moesia Superior, in: The Archaeology of Water Supply, British Archaeological Reports S2414, ed. M. Żuchowska, 27-39. Oxford: Archaeopress. 
Krencker, D., Krüeger, E., Lehtman, H., Wachtler, H. 1929. Die Trierer Kaiserthermen. Trierer Grabungen und Forschungen, Bd. I, Augsburg: Dr. Benno Filser Verlag.

Kuzmanović Novović, I., Janković, M., Manojlović Nikolić, V. 2019. Bathing in the Roman Province: Local characterstics of baths in Moesia Superior. Journal of historical researches 30: 24-44.

Јеремић, Г., Гојгић, А. 2012. Римске терме у Чачку. Чачак: Народни музеј.

Јордовић, С̆. 1999. Римске терме у селу Баце, у: Прокупље у праисторији, антици и средњем веку, ур. М. Васић и Д. Маринковић, 197-199. Београд-Прокупље: Археолошки институт и Музеј Топлице.

Maréchal, S. 2015. Lauacrum: just another word for baths? How the terminology of baths may have reflected changes in bathing habits. Revue belge de Philologie et d'Histoire 931: 139-177.

Maréchal, S. 2012. Research on Roman bathing: Old theories, new conclusions. Revue belge de Philologie et d'Histoire 90-1: 143-164.

Nikolić, E., Rogić, D., Milovanović, B. 2014. The role of brick in hydraulicity of Viminacium mortars: decorative mortars from the thermae, Arheologija i prirodne nauke $=$ Archaeology and Science. Br. 10 (2014), str. 71-92

Nielsen, I. 1993. Thermae et Balnea. The Architecture and Cultural History of Roman Public Baths, Vols. I-II. Aarhus: Aarhus University Press.

Overbeck, J., 1884. Pompeji, in seinen gebauden, alterturmen und kunstwerken. Leipzig: Verlag von Wilhelm Engelmann.

Оршић-Славетић, А., 1933-1934. Археолошка ископавања у Нишу и околини. Старинар (трећа серија) VIII-IX, 303-310.

Parović-Pešikan, M. 1969. Pokušaj rekonstrukcije peristila kasnoantičke vile u Sirmijumu. Starinar XX: 265-276.

Pasqui, A. 1897. La Villa Pompeiana della Pisanella presso Boscoreale, Monumenti Antichi VII: 397-554.

Петковић, С., 2010. Ромулијана у време после царске палате, у Felix Romuliana Гамзиград, ур. И. Поповић, 167-200. Београд: Археолошки институт.

Petrova, S. 2012. Nicopolis ad Nestum / Mestum, in: Roman Cities in Bulgaria. Corpus of Ancient and Medieval settlements in modern Bulgaria Bd. 1, ed. R. Ivanov, 289-361. Sofia: Prof. Marin Drinov Academic Publishing House.

Петровић, П. 1982-1983. Поречка река, сабирни центар за снабдевање римских трупа у Ђердапу. Старинар XXXIII-XXXIV: 285-291.

Петровић, П. 1994. Медијана. Резиденција римских цзарева, Београд - Ниш: САНУ, Археолошки институт у Београду, Народни музеј у Нишу.

Petrović, P. 1995. Timacum Minus et la vallee du Timok, Inscriptions de la Mesie Superieure III-2. Beograd: Centre d'études épigraphiques et numismatiques de la Faculté de philosophie de l'Université de Beograd.

Petrović, P., Vasić, M., 1996. The Roman frontier in Upper Moesia: Archaeological Investigations in the Iron Gate Area - Main Results, in: Roman Limes on the middle and lower Danube, ed. P. Petrović, 15-26. Belgrade: Archaeological Institute, 
Петровић, П., Јовановић, С. 1997. Културно благо књажевачког краја. Археологија. Београд-Књажевац: Археолошки институт у Београду и Завичајни музеј у Књажевцу. Петровић, П. 1999. Ниш у античко доба, Ниш: Просвета.

Petrović, V., Filipović, V. 2008. Locating the Timacum Maius station on the roman road Lissus-Naissus-Ratiaria: New archaeological research. Balcanica 39: 47-58.

Rebuffat, R. 1991. Vocabulaire thermal. Documents sur le bain romains, in: Les thermes romains, Actes de la table ronde organisée par l'École Française de Rome, 11-12 novembre 1988, ed. R. Rebuffat, 1-34. Rome: Collection l'École Française de Rome.

Revell, L. 2007. Military Bath-Houses in Britain: A Comment. Britannia 38: 230-237.

Sedlmayer, H. 2017. Sedlmayer, 15 Analogien des römischen BadegeBäudes von Bratislava-Dúbravka im Blocktyp, in: Bratislava-Dúbravka im 1. bis 4. jahrhundert n. Chr., Germanischer Fürstensitz und die germanische Besiedlung, ed. K. Elschek, 358-375. Nitra: Archeologický ústav Slovenskej akadémie vied.

Suceveanu, A., Sion, A., Poenaru Bordea, G., Vecerdea, G. 1982. Histria VI: Les Thermes romains. Bucarest: Ed. Acad. Rep. socialiste Romana; Paris : Diff. de Boccard. Талевски, Џ. 2018. Раноримското наследство и потенцијалните влијанија врз станбената и сакралната архитектура во доцноримските урбани средини на територијата на република Македонија. Balcanoslavica 47(1): 25-43.

Taylor, R. 2008. Roman Builders - A study in architectural process. Cambridge: Cambridge Univeristy Press.

Ţentea, O., Burkhardt, B. 2017. Baths on the Frontiers of Roman Dacia, Roman Frontiers in Romania. Bucurest: Mega Publishing House.

Томовић, М., Булатовић, А., Капуран, А. 2005. Жујинце - Црквиште. Терме, у: Археолошка истраживања. E-75. Свеска 1/2004, ур. М. Брмболић, 317-353. Београд: Републички завод за заштиту споменика културе.

Fagan, G. 1993. Three studies in Roman public bathing: origins, growth, and social aspects. $\mathrm{PhD}$ dissertation, Hamilton, Ontario: McMaster University.

Fagan, G. 1999. Bathing in public in the roman world. Ann Arbor: University of Michigan Press.

Fagan, G. 2001. The genesis of the Roman public bath: recent approaches and future directions. American Journal of Archaeology 105: 403-26.

Fournet, T., Redon, B. 2013. Heating Systems of Greek Baths - New Evidence from Egypt, in Greek baths and bathing culture - new discoveries and approaches, ed. S. K. Lucore and M. Trümper, Babech Suplements 23, 239-263. Leuven: Peeters.

Campbell, D. B. 2009. Roman Auxiliary forts 27 BC-AD 378. Oxfrord: Osprey Publishing. Чанак Медић, М., Стојковић-Павелка, Б., 2010. Архитектура и просторна структура царске палате, у Felix Romuliana - Гамзиград, ур. И. Поповић, 49-106. Београд: Археолошки институт.

Чершков, E. 1970. Municipium D.D. kod Sočanice. Priština-Beograd: Muzej Kosova i Arheološko društvo Jugoslavije.

Yegül, F. 1992. Baths and Bathing in classical antiquity. Cambridge - New York: The MIT Press. 


\title{
Igor Bjelić
}

Institute of Archaeology, Belgrade

\section{CALDARIA WITHIN SMALL ROMAN BATHS THROUGH ANALYSES OF EXAMPLES FROM EASTERN AND SOUTHERN SERBIA: BUILDING CONCEPT AND FURNISHING}

\author{
Keywords: caldaria, Roman bath, Late Antique architecture, \\ eastern and southern Serbia
}

This paper studies the caldaria of several baths in the territory of southern and eastern Serbia. During the review of scientific literature dealing with baths in this area, it was noticed that, until recently, there was a certain degree of confusion regarding the identification of these rooms in some examples. It was caused by a lack of clear criteria on this issue, which was the reason for our review.

In the first part of the paper, we have pointed out several characteristics, widely present in world-wide scientific literature, through which caldaria could be more easily registered during and after archaeological research. The basic recognition factors are the specific plan of a caldarium and its position in regard to the prefurnium and the position of the entrance to the building.

In the second part, we have pointed out that, in the territory of southern and eastern Serbia, the usual shape of the plan of this room implies a central rectangular space with a rectangular annex on the side towards the prefurnium and one to two semi-circular annexes. Caldaria are regularly the rooms that are farthest from the entrances of small baths. The heating installations, water supply, outflow channels, constructions for bathtubs and vaults, and the presence of specific materials (primarily hydraulic mortar) were analysed as secondary recognition elements. In the construction of wall-heating, the presence of specific elements such as tegulae mammatae, terracotta spacers, T-nails, and tubulii was considered. The largest number of caldaria in the territory of southern and eastern Serbia is characterised by the same building features as the caldaria of other baths in the area, as well as those in the wider area of the Roman Empire. 